\title{
Responses of Phyllosphere Microbial Population of Some Common Road Trees In Relation To Dust Deposition - A Case Study in Kolkata, India
}

\author{
Amrita Chaudhuri ${ }^{1}$, S C Santra ${ }^{1}$ \\ 1. (Department of Environmental Science, University of Kalyani, Nadia-741235, West Bengal, India.)
}

\begin{abstract}
In the present paper, the effect of urban roadside air pollution on the epiphytic micro flora was studied on three most common plants of urban area i.e. Ficus religiosa, Ficus benghalensis and Anthocephalus cadamba at Kolkata. The increasing rate of vehicles day by day simultaneously increases the pollution level in air and the dust settled down on the phylloplane of those plants. In this study, samples were collected from Dunlop (direct roadside) and Rajarhat (from at least 500-750 meter away from direct roadside or non-roadside sites).Results showed a marked reduction of the microbial count on the roadside environment than the nonroadside environment. Bacterial and fungal population was higher on the low polluted site. Analysis of four different trace metals was carried out from the phylloplane of the aforesaid trees. Correlation coefficient showed significant reduction of microbial community in Dunlop due to the higher concentration of lead, zinc, copper and Cadmium. Presence of traffic generated pollutant might be a cause of decrease in growth for microbes.Aspergillusochraceus, Penicilliumfrequentaus, Trichodermaviridewere the most abundant species in roadside environment, whereas absence of fungi like Penicilliumcitrinum, Aspergillusnigerwere observed in roadside environment. The deviation of fungal population diversity might be occurred due to its sensitivity or resistance to the pollutants with those fungi.
\end{abstract}

Keywords:Air pollution, diversity index, microbial population, phyllosphere, SEM.,

\section{Introduction}

Phyllosphere, being a rich and complex habitat for microorganism, is a larger space for both agricultural and environmental important microbes. According to a group of researchers [1-3] a large array of culture dependent and independent bacteria, fungi, yeast and algae are found on the phylloplane, known as epiphytic microbes. Different studies have been revealed that bacteria are the most dominant microbes on phyllosphere, average population is $10^{6}-10^{7} \mathrm{CFU} \mathrm{\textrm {cm } ^ { - 2 }}$ (up to $10^{8} \mathrm{CFU}$ per gram) of leaf [4,5]. It is also noticed that the presence of culturable bacteria is ranging between $10^{2}$ and $10^{12}$ cells per gram of leaf in arid conditions of Mediterranean summer [6-8]. The growth of phylloplane microbes generally depends on various biotic and abiotic factors.

In today's world industrialization and urbanization are the most important factors of air pollution. The main sources of urban air pollutants are coming from fossil fuel driven motor vehicle emission and other sources are workshops, and residential heating etc. These problems are increased day by day not only for the population growth but also for narrow and congested road and old poorly maintained vehicles. A wide assortment of toxins like benzene, carbon monoxides, organic compounds, nitrogen and sulfur dioxides discharged each day from vehicles. Leaf surface of plants which are located beside the high roads are generally trapped the dust and air borne pollutants. Different metal of air pollutant leaches on the leaf surface and interact with the microbes. The interaction between them can alter and affect the activity of microorganisms on phyllosphere. In Kolkata metropolitan city traffic induced aerosols consist of huge number of elements, which are $\mathrm{K}, \mathrm{Ca}, \mathrm{V}, \mathrm{Cr}, \mathrm{Mn}, \mathrm{Fe}$, $\mathrm{Co}, \mathrm{Ni}, \mathrm{Cu}, \mathrm{Zn}, \mathrm{Se}$ and $\mathrm{Pb}$.It also shows that the concentration of metals are generally ranges in the order of $\mathrm{Zn}>\mathrm{Pb}>\mathrm{Ni}>\mathrm{Cu}>\mathrm{Cr}>\mathrm{Co}[9]$. Previous study [10] showed different plants like Azadirachtaindica, Terminaliacatapa, Ficus religiosa and Ficus benghalensis aregood indicator of pollution level in urban and peri urban environment by their leaf surface in Jalgaon city. It was reported [11] that Ficus benghalensis and Polyathialongifolia can capture dust ranging between $0.12 \mathrm{mg} / \mathrm{cm}^{2}$ to $1.89 \mathrm{mg} / \mathrm{cm} 2$ in urban areas of Kolkata mainly in Salt Lake region on both adaxial and abaxial surfaces.

Disturbances on plant-microbe association can obstruct different type of non-pathogenic activity i.e. nitrogen fixation, degradation of waxes, production of growth hormones and biological control of pathogenic bacteria [12-14]. The alteration of leaf surface by microbial population isexplained by a group of researchers $[2,15,16$,$] . Interaction with the air contaminants can causes direct effect on the biological control of leaf$ pathogen, when antagonist is very much sensitive with the contaminants [17]. Chronic exposure of $\mathrm{SO}_{2}$ in polluted areas causes loss of phyllosphere fungi and in short term exposure no significant loss was observed by studies [18]. 
Pollutant like gaseous and atmospheric aerosols directly alters microbial biodiversity [19]. The bacterial population decreases with high metal concentration of air pollutants, near to the traffic congested sites. However, in case of fungi, total count may be higher sometimes near the roadside for the low $\mathrm{pH}$ concentration [20].A Study in North Eastern region of India revealed that the number of fungal and bacterial significantly decreased with the increasing amount of roadside pollution level in Alnusnepalensisand Pinuskesiya. Microbes are generally negatively correlated with different metal like Zinc, Lead Copper, Cadmium and Sulfur [21].The growth of bacteria, filamentous fungi and yeast on the leaf surface of trees like mango [22] are also affected by different chemical sprays.

Not many studies have been done in India particularly in Kolkata to understand the interaction between the phyllosphere bacteria and fungi with air particulate in the phylloplane of roadside plant [23-26]. The present study is therefore to investigate the trend of microbial population on the road side plant phyllosphere, which are affected by vehicular dust and also to investigate the impact of pollutants over the population dynamics of the microbes.

\section{Materials and Methods}

Kolkata $\left(22^{\circ} 82^{\prime} \mathrm{N}\right.$ and $\left.88^{\circ} 20^{\prime} \mathrm{E}\right)$ is one of the oldest metropolitan cities of India, densely populated and immensely polluted. The study was conducted on the month December 2013. Roughly 16 million people are to be found on the city of joy and this number of inhabitants is increasing day by day. Increasing amount of high rise, roads, bridges as well as growing transportation system causes rapid urbanization on this city, which are the major contributor of particulate emission in air. The analysis was done in two sites i.e. Dunlop (site $\left.1 / \mathrm{S}_{1}\right)$ $\left(22^{\circ} 38^{\prime} \mathrm{N}\right.$ and $\left.88^{\circ} 61^{\prime} \mathrm{E}\right)$, and Rajarhat (site $\left.2 / \mathrm{S}_{2}\right)\left(22^{\circ} 35^{\prime} \mathrm{N}\right.$ and $\left.88^{\circ} 28^{\prime} \mathrm{E}\right)$. The air quality of the study sites was obtained from the available data in the website of West Bengal Pollution control board (WBPCB) as they have monitoring station in both polluted sites described here. In Dunlop, heavy load of traffic and other activities were seen during the busy day time (5000-6000 vehicles/hour). Anothersitewas less affected by traffic vehicle as it was a constructional area and plants are more than 500 meters away from the actual roadside, mainly covered by tall buildings (non-roadside environment). This site was considered as less polluted and nonroadside location. Three dominant, broad leaves, evergreen plants, Ficusreligiosa linn(Peepal) indicated as $\mathrm{P}_{1}$, Ficus benghalensis linnindicated as $\mathrm{P}_{2}$ (Banyan), Anthocephalus cadamba(Roxb.) Miq. Syn. Neolamarckia cadamba var A. chinensis (Kadam) indicated as $\mathrm{P}_{3}$ were selected for this analysis in both sites.

Full mature, green leaves of both plants were collected from the sites from an elevation of $5 \mathrm{ft}$ approx. Samplings ware done in the early morning. Five mature leaves samples were collected from $\mathrm{P}_{1}, \mathrm{P}_{2}$ and $\mathrm{P}_{3}$ at the two sites in sterilised zipper bags and transported for microbial assay in between twenty-four hours to laboratory. Microbial analysis by isolation of micro-fungi and bacteria was done by serial dilution method as described by Joshi [21]. One gram of leaf sample was weighed and taken in a 250-ml conical flask containing $100 \mathrm{ml}$ of sterilised distilled water. Then it was shaken rapidly for about half an hour for remove the phylloplane or leaf surface microbes. Then from the original wash, suitabledilutation of the suspension was prepared. $0.5 \mathrm{ml}$ suspension was plated aseptically in to sterile petriplate containing nutrient agar medium and czapec-dox media for bacteria and fungi respectively. For each sample three replicas were done and the petridisheswere incubated at $37 \pm 1^{\circ} \mathrm{c}$ and $27 \pm 1^{\circ} \mathrm{c}$ for bacteria and fungus respectively. Total CFU (colony forming unit) of fungi and bacteria at per gram of leaf were calculated, depending on the dilution factor.

\subsection{Calculation for relative abundance (1), Shannon index (2) and species richness (3) in sites}

The formula for calculating the relative abundance of fungi is:

Relative abundance $=($ Total number CFU of individuals/Total no of CFU of all the species $)$ X 100...(1)

The formula for calculating the Shannon diversity index of fungi is: [27]

$\mathbf{S}$

$\mathbf{H}=\sum_{\mathbf{i}=\mathbf{1}}-\left(\mathbf{P}_{\mathbf{i}} * \ln \mathbf{P}_{\mathbf{i}}\right)$

where:

$\mathrm{H}=$ the Shannon diversity index

$\mathrm{Pi}=$ fraction of the entire population made up of species $\mathrm{i}$

$\mathrm{S}=$ numbers of species encountered

$\sum=$ sum from species 1 to species $\mathrm{S}$

Species richness index is calculated by

Species richness $=(\mathrm{S}-1) / \log \mathrm{N}$

Where, $S=$ number of fungal species.

$\mathrm{N}=$ Total number of Fungi 
Responses of phyllosphere microbial population of some common road trees in relation to dust ..

\subsection{Analysis of metal in the leaf samples $(\mathrm{Pb}, \mathrm{Cu}, \mathrm{Zn}, \mathrm{Cd})$}

At first leaf sample was dried and powdered.0.5 gram of leaf dust was taken in triplicate ata digestion tube, then it was kept for overnight and digested with $20 \mathrm{ml}$ of concentrated Nitric acid. Then the extracts were filtered and volume made up to $50 \mathrm{ml}$ with distilled water. Then the sample concentration (ppm) was measured on Perkin Elmer (A400) atomic absorption spectrophotometer.

\subsection{Direct examination of leaf Surface}

Imageries were taken by scanning electron microscope as described by Ram et al.[28]. Small pieces of leaves $(1 \mathrm{~cm} 2)$ were cut from undisturbed sample by a sharp blade. Then it was air dried in a clean and close chamber and small strips were sliced from each leaf from the middle and marginal area. Each leaf strip was mounted on aluminium stab and coated by thin layered gold (about $200^{\circ} \mathrm{A}$ ), which was conductive in nature, in an ion sputter coater (GIB2). Then the image of the coated sample was taken in scanning electron microscopy (Hitachi, S530).

\subsection{Statistical Analysis}

The correlation coefficient was calculated using Pearson's correlation coefficient. These analyses weredone by using SPSS for windows. (SPSS Statistics v21)

\section{Result and discussion}

The air quality of the study sites ware shown in "Table1". Itwas seen that levels of SPM and RSPM were quite higher than the national standards of air quality at both sites. But in case of $\mathrm{NO}_{2}$ only Dunlop showed high values than the national standards, whereas in case of $\mathrm{SO}_{2}$ it was lower than the standards in both instances.

Table 1:Pollution levels in study sites and standard parameters of air pollutants.

\begin{tabular}{|c|c|c|c|c|}
\hline Sites & $\mathrm{SO}_{2}$ & $\mathrm{NO}_{2}$ & $\mathrm{SPM}$ & $\mathrm{RSPM}$ \\
\hline Dunlop & $6.825 \pm 0.88$ & $61.975 \pm 5.40$ & $205 \pm 41.32$ & $100 \pm 12.16$ \\
\hline Rajarhat & $4.975 \pm 0.499$ & $42.775 \pm 4.18$ & $177 \pm 26.73$ & $88 \pm 8.26$ \\
\hline Standard* & 60 & 60 & 140 & 60 \\
\hline
\end{tabular}

All values in $\mu \mathrm{g}$ per $\mathrm{m}^{3}$

*Air quality standard values of West Bengal pollution control board.

Plant canopy acts as a nature's absorbing surface with a suitable surface area for dust deposition. Dust particles were found to attach on both the surfaces, adaxial and abaxial surfaces of all the three plants. Scanning electron microscopy of the leaf sample phylloplane, collected from Rajarhat $\left(S_{2}\right)$, revealed small growth of fungal conidiophores emerged out near the stomatal pore and different fungal thread like hyphae, surrounded by atmospheric dust and leaf trichomes (figure 1a), but no such association is found from $\mathrm{S}_{1}$ samples, roadside environment "Fig.1". Maximum dust particle was seen on the upper surface of leaves. Stomata are acting like key passages for the transport of moisture and nutrient around the cuticle layer of the leaf surface, which helps to harbour the microbial community. Theresuspended dusts usually block the stomata on the roadside plants and act as a barrier. Hence, absence of fungal growth was seen on the roadside plant of these study and a small emerging conidiophore as well as fungal hyphae was seen to start near the stomata of non-roadside plant. No microbial association could not be find on the phylloplane of Roadside samples. This might be because ofstomatal pore of the plant situated on the roadside environment was blocked by the dust particles (Fig.2a), whereas the upper surface of the phylloplane was also covered by metal contaminated dust particles (Fig.2b). Microbial colony distribution was mainly seen on the lower surface of phylloplane by the direct microscopy. All these three plants in the roadside area showed the ability to capture the re suspended dust. A study by Prajapati and Triphathi [29] suggested that dust deposition generally depend on various factors like leaf size and structure, their epidermal traits, and on their leaf surface characteristics like trichrome, hair, cuticles etc. Ficus Benghalensishad greater efficiency of dust adsorption so there are chances to use it as passive air pollution monitor. Mafia et al. [30] was observed the occurrence of fungal community on the lower surface of leaf of Eucalyptus spp. They also observed the growth of fungal colony at close to leaf stomata. Theabaxial surface of leaf generally consist more number of trichrome, stomata [31].Even another colonizing microbes, bacteria tends to colonize at the lower surface of bacteria, near the stomata and trichrome. This observation was supported by a group of researchers [32-33]. The large flux of UV radiation, water and nutrient availability were the major factors for microbial growth in phylloplane. It was seen that microbes of leaf habitat were very much affected by such rapid fluctuations of different physical conditions than that of other habitats. 

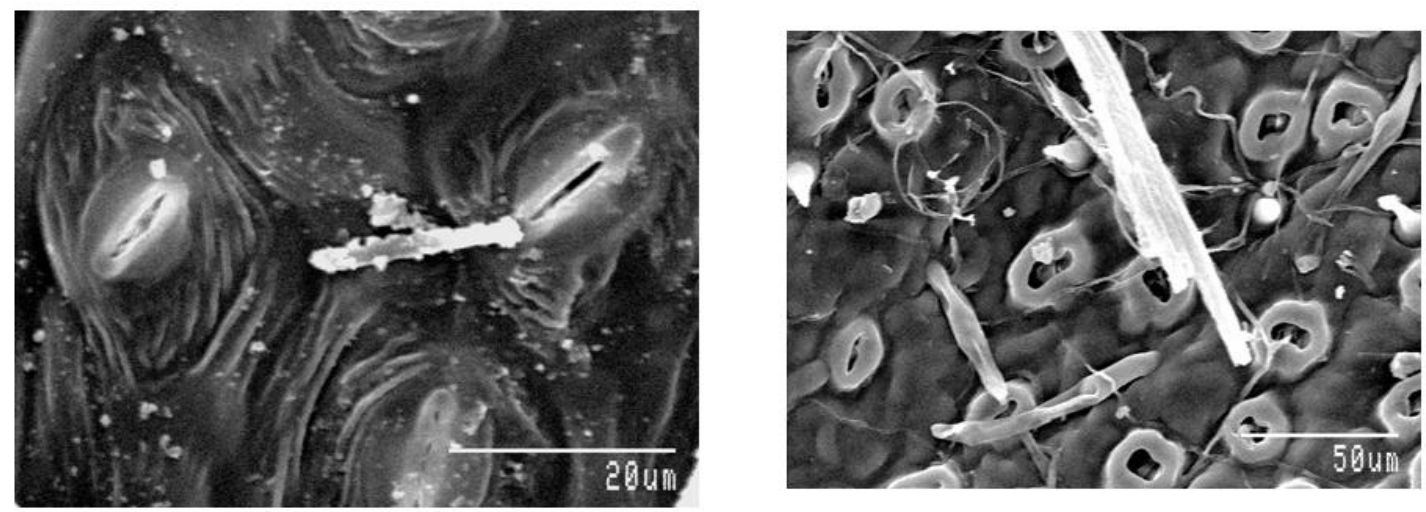

Figure 1: SEM microgragh showing the conidiophore emerges out near the stoma and hyphal growth of fungi near the stoma of $F$. benghalensis.ofsite $S_{1}$.
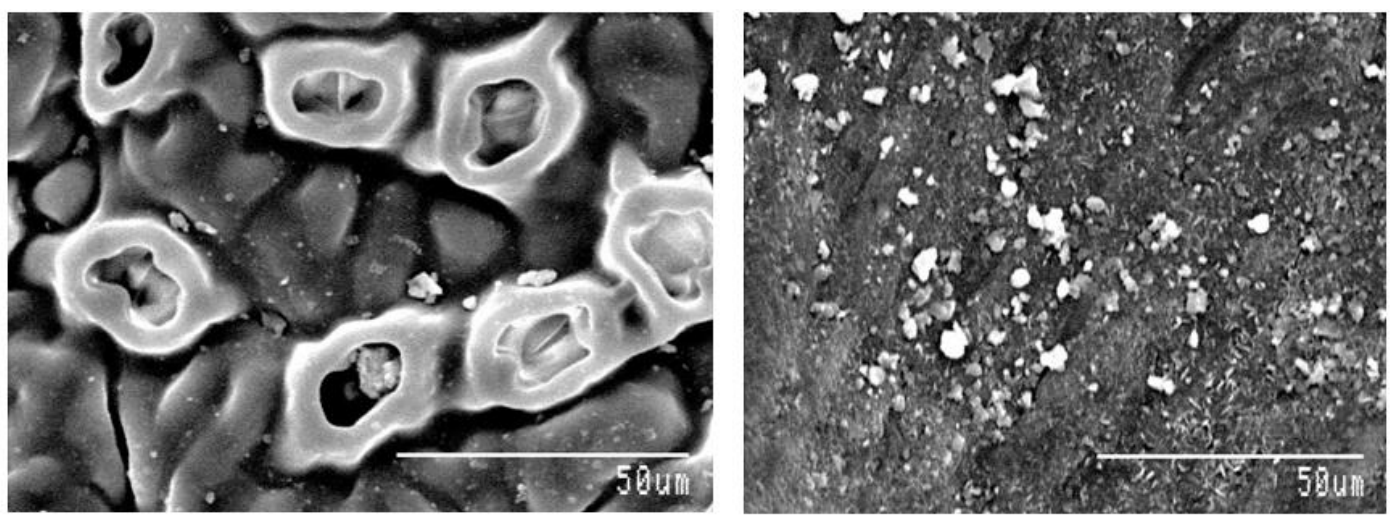

(A) Stomata blocked by dust particles

(B) upper surface of leaf covered by dust particles.

Figure 2: Scanning electron micrograph of stomatal dust deposition on the phylloplane of roadside plant of site $S_{1}$

The size of microbial population $\left(S_{1}\right.$ and $\left.S_{2}\right)$ of the three plant's phylloplaneis represented on "Fig 3". In our studyphylloplane microbial population showed a reduction of number in roadside location $\left(\mathrm{S}_{1}\right)$ than the nonroadside environment $\left(S_{2}\right)$. Number of bacteria and fungi were decreased at polluted or roadside environment in compare with non-roadside environment. A considerable difference in the level of bacterial and fungal colony in the phylloplane of the two sites was noticed. Due to vehicular pollution of roadside site a significant decrease in bacterial and micro fungal community of phylloplane was occurred. Presence of different vehicular exhausting metals was greater in the roadside site in compare to the non-roadside site (Fig 4).The fluctuation of CFU of bacteria and fungi clearly showed a negatively significant correlation with the variation in labels of $\mathrm{Pb}, \mathrm{Zn}, \mathrm{Cd}$ and $\mathrm{Cu}$ in polluted site but in non-roadside sampling site elevated count of microbial populations wasfound, which was not significant between those trace metals and samples collected from the sampling site of Rajarhat $\left(\mathrm{S}_{2}\right)$.Dust deposition on the phylloplane of the three plants left a damaging effect on the microbial community of the phyllosphere shown by the coefficient correlation data analysis "Table 2". These findings were supported by Joshi [21]. That study reflected decrease of bacteria and fungi with increase of pollution at roadside site. Again, De Jageret al. [22] reported the loss of microbial community due to chemical spray on leaf surface. Even lichen was also adversely affected by air pollution as described by Monge-Najeraet al.[34]. Similarly, a study by Sandhuet al. [35] also indicated the detrimental effect of the air pollutants over the other group of bacteria than some air borne phenol tolerant microbes. CFU fluctuation and fungal species variation was also indicated the study bacterial population on dusty hemlock leaves [36]. Another study by Mohamed and Abo-amer [20] revealed that higher heavy metal concentration caused lower in bacterial counts in both phylloplane and soil;however, the fungal count might be higher in some roadside areas because of the acidic condition as it was favourable for fungal growth. 
Figure 3:Bacterial and fungal population of the phyllosphere of three plants situated on the roadside environment and non-road sideenvironments. Bar represents the mean values of $\mathrm{CFUx} 10^{4}$

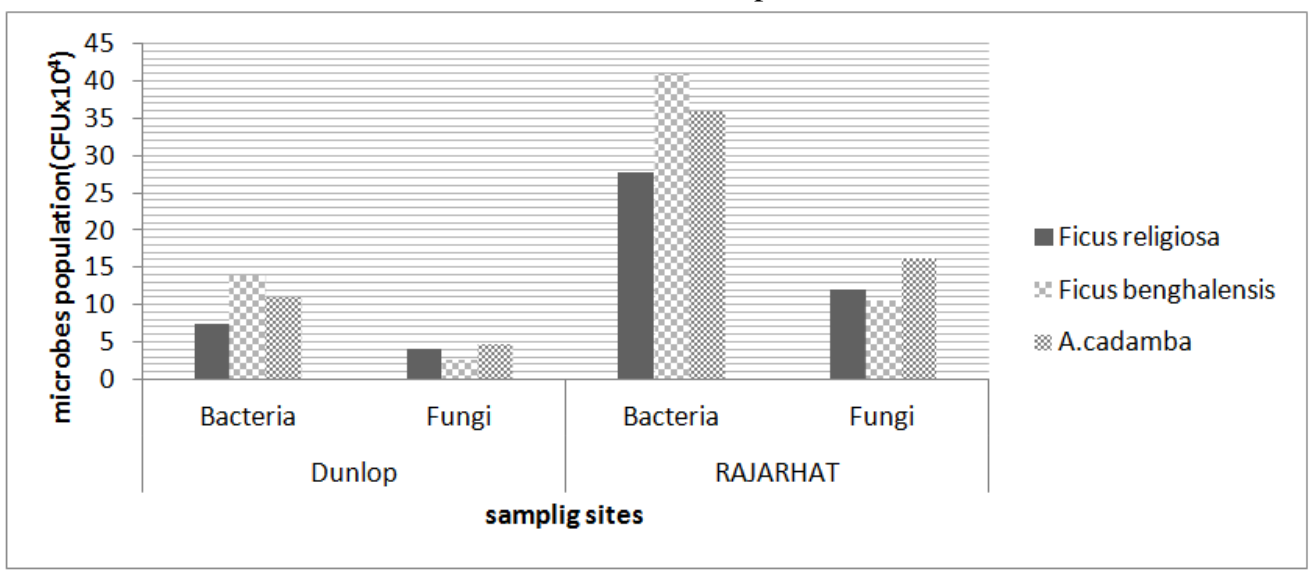

Table 2 :Correlations coefficients for $\mathrm{Pb}, \mathrm{Cu}, \mathrm{Zn}, \mathrm{Cd}$,fungal and bacterial population on phyllosphere of trees at roadside site.

\begin{tabular}{|c|c|c|c|c|c|}
\hline \multirow[t]{2}{*}{ Sources of variation } & \multirow[t]{2}{*}{$\mathrm{DF}$} & \multicolumn{2}{|l|}{ Roadside site } & \multicolumn{2}{|l|}{ Non-roadside site } \\
\hline & & Bacterial population & Fungal population & Bacterial population & Fungal population \\
\hline $\mathrm{Pb}$ & 9 & $-.872^{* *}$ & $-.901^{* *}$ & -.699 & -.310 \\
\hline $\mathrm{Cu}$ & 9 & $-.879^{* *}$ & $-.787^{*}$ & -.654 & -.315 \\
\hline $\mathrm{Zn}$ & 9 & $-.861^{* *}$ & -.749 & -.525 & -.204 \\
\hline $\mathrm{Cd}$ & 9 & $-.939^{* *}$ & $-.900^{* *}$ & -.590 & -.112 \\
\hline
\end{tabular}

** Correlation is significant at the 0.01 level (2-tailed).

* Correlation is significant at the 0.05 level (2-tailed).

Total number of eight fungal species was identified out of twenty-three fungal types the leaf surface of those trees from $S_{1}$ and $S_{2}$. From these, six species were isolated from the site $S_{1}$, the roadside location and eight species were recorded from $\mathrm{S}_{2}$, the non-roadside location. The isolated strains from $\mathrm{S}_{1}$ were Aspergillusglacus, Aspergillusflavus, Penicilliumfrequentaus, Aspergillusochraceus, Penicilliumcitrinum, Trichodermaviride. Aspergillusniger.Penicilliumcitrinumwas specific in non-roadside environment only. No fungal colony of above said strain could be found on $S_{1}$, which indicated its tendency of sensitivity to the pollutant site. CFU of Aspergillusochraceus and Penicillumfrequentaus were more dominant in roadside environment.In case of nonroadside location $\mathrm{S}_{2}$,Trichodermaviridewas showed the highest abundance (shown in Table 3). Shannon diversity index, similarity index of fungal population was also observed and demonstrated in table 4 for the three plants in both locations (shown in table 4). The fungal population in terms of number of CFU and species richness was higher in the non-roadside environment, which might cause due to little lesser deposition of dust particle on the leaf phylloplane (Table 4). The predominance of Penicilliumfrequentaus showed its resistance power against the pollutants and modification of its spore germinating capacity. Fluctuation of CFU might be occurred due to change of relative humidity, temperature, rainfall. These factors directly affect the pollutants or the dust depositions on the leaf surface. Mowllet al. [37]showed a distinct difference of fungal count between polluted and non-polluted sites, affected by vehicular air pollutants. A significant reduction of fungal colony with increasing toxicity was seen in different studies [38]. Different element like $\mathrm{Na}, \mathrm{Mg}, \mathrm{Al}, \mathrm{Si}, \mathrm{Cl}, \mathrm{K}, \mathrm{Ca}, \mathrm{Cr}, \mathrm{Mn}$, $\mathrm{Fe}, \mathrm{Ni}, \mathrm{Cu}$ and $\mathrm{Zn}$ were the major component in the dust deposition [11]. This deposit above a specific range turned into toxic substance and hampered the colonization of microbes. It was the one of the reasons of less number of population densities of microbes in the roadside environment.

Table 3:Relative abundance (\%) of fungal species on leaf surface of three plants $\left(\mathrm{P}_{1}, \mathrm{P}_{2}\right.$ andP $\left.\mathrm{P}_{3}\right)$ at roadside and non-roadside location $\left(\mathrm{S}_{1}\right.$ and $\left.\mathrm{S}_{2}\right)$

\begin{tabular}{|c|c|c|c|c|c|c|}
\hline \multicolumn{3}{|c}{ Dunlop $\left(\mathrm{S}_{1}\right)$} & \multicolumn{4}{c|}{ Rajarhat $\left(\mathrm{S}_{2}\right)$} \\
\hline Fungal strains & $\mathrm{P}_{1}$ & $\mathrm{P}_{2}$ & $\mathrm{P}_{3}$ & $\mathrm{P}_{1}$ & $\mathrm{P}_{2}$ & $\mathrm{P}_{3}$ \\
\hline Aspergillusglacus & 16.66 & 13.33 & 9.52 & 10.31 & 13.46 & 14.85 \\
\hline Aspergillusflavus & 15 & 16.66 & 13.12 & 21.58 & 9.76 & 11.01 \\
\hline Aspergillusniger & - & - & - & 9.91 & 8.62 & 15.11 \\
\hline Penicillumfrequentaus & 17.77 & 40 & 17.85 & 14.76 & 23.68 & 19.64 \\
\hline Aspergillusochraceus & 32.77 & 23.33 & 21.46 & 6.66 & 9.76 & - \\
\hline Penicilliunmpallidum & 11.11 & 6.66 & - & - & 14.42 & 11.33 \\
\hline Penicilliumcitrinum & - & - & - & 13.09 & 5.59 & 9.18 \\
\hline Trichodermaviride & 6.66 & - & 38.12 & 23.64 & 14.68 & 18.83 \\
\hline
\end{tabular}


Responses of phyllosphere microbial population of some common road trees in relation to dust ..

Table 4:Index of diversity, species richness and similarity index of two sites $\left(\mathrm{S}_{1}\right.$ and $\mathrm{S}_{2)}$

\begin{tabular}{|c|c|c|c|c|c|}
\hline \multicolumn{3}{|c|}{ Dunlop } & \multicolumn{3}{c|}{ Rajarhat } \\
plants & Species richness & Shannon index & Species richness & Shannon index & Similarity index \\
\hline $\mathrm{P}_{1}$ & 2.48 & 1.55 & 5.05 & 1.871 & 76.92 \\
\hline $\mathrm{P}_{2}$ & 2.96 & 1.56 & 7.12 & 2.011 & 76.92 \\
\hline $\mathrm{P}_{3}$ & 2.5 & 1.57 & 4.54 & 1.92 & 83.33 \\
\hline
\end{tabular}

$* \mathrm{P}_{1}, \mathrm{P}_{2}$ and $\mathrm{P}_{3}$ represent three plants F.religiosa,F.benghalensis and A.cadamba respectively.

\section{Conclusion}

Our findings revealed that reduction of total microbial population in roadside environment than the non-roadside environment. Fungal association was directly seen by microscopy near the stomata at the lower surface of the phylloplane of less polluted zone, which indicated its sensitivity to the dust as well as toxic metal contaminated with dust particles. Stomata generally act as a direct passage for water transportation. Covering of stomata with dust causes the disturbance between the plant and microbe interaction, it affects adversely on the microbial population. An extensive and further research is needed in this area to describe the proper mechanism of the interaction of air pollutants and microbial association. Among which the complex area of heavy metal pollution and microbial association is need to be exposed, to identify the potentiality of those microbes as bio remediation agents.

\section{Acknowledgments}

This study was financially supported by Department of Science and Technology (DST), Government of India (DST-INSPIRE). Authors were grateful to USIC Department, Bardwan University, where the Scanning Electron microscopy has been carried out. Authors are also thankful to SoumePyne from Kalyani University for helpful comments.

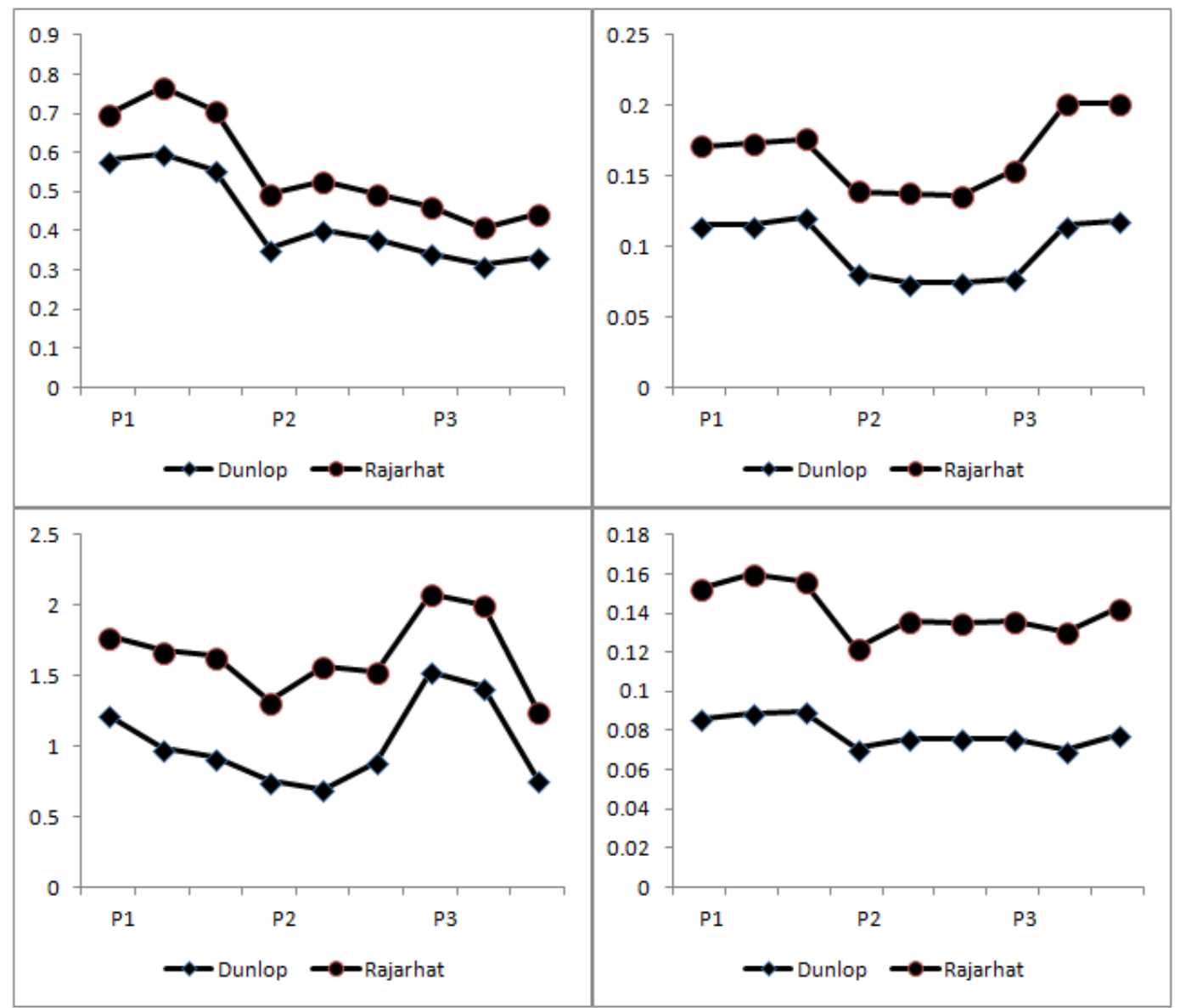

Figure 4.Variation of the concentration (ppm) of $\mathrm{Pb}, \mathrm{Cu}, \mathrm{Zn}$ and $\mathrm{Cd}$ in the phylloplane of roadside $\left(\mathrm{S}_{1}\right)$ and nonroadside $\left(\mathrm{S}_{2}\right)$ plants. $\mathrm{P}_{1}, \mathrm{P}_{2}$ and $\mathrm{P}_{3}$ represent three plants F.religiosa,F.benghalensis and A.cadamba respectively. 


\section{References}

[1]. S. E. Lindow, and J. H .J .Leveau, Phyllosphere microbiology, Curr.Opin.Biotechnol., 13,2002,238-243.

[2]. S. E. Lindow, and M. T .Brandl, Microbiology of the phyllosphere, Appl Environ Microbiol, 69, 2003,1875-1883

[3]. J. M. Whipps, P. Hand, D. Pink, and G. D. Bending, Phyllosphere microbiology with special reference to diversity and plant genotype, Journal of Applied Microbiology, 105.6, 2008,1744-1755.

[4]. J. H. Andrews, and R.F.Harris, The ecology and biogeography of microorganisms of plant surfaces, Annu Rev Phytopathol,38, $2000,145-180$

[5]. S. S. Hirano, and C. D. Upper, Bacteria in the leaf ecosystem with emphasis on Pseudomonas syringae-a pathogen, ice nucleus, and epiphyte, Microbiol Mol Biol Rev,64, 2000 ,624-653.

[6]. I. P. Thompson, M. J. Bailey, J.S. Fenlon, T. R. Fermor, A. K. Lilley, J. M. Lynch, and J. M. Whipps, Quantitative and qualitative seasonal changes in the microbial community from the phyllosphere of sugar beet Beta vulgaris, Plant Soil, 150, 1993,177-191.

[7]. J. Inacio, P. Pereira, D.M. Carvalho, A. Fonseca, M.T. Amaral-Collaco, I. Spencer-Martins, Estimation and diversity of phylloplane mycobiota on selected plants in a Mediterraneantype ecosystem in Portugal, Microb Ecol, 44, ,2002, $344-353$.

[8]. R.K.P. Yadav, J.M. Halley, K. Karamanoli, H. I. Constantinidou, and D. Vokou, Bacterial populations on the leaves of Mediterranean plants, quantitative features and testing of distribution models, Environ. Exp. Bot.,52, 2004,63-77.

[9]. S. Kar, J.P. Maity, A.C. Samal, and S.C. Santra, Metallic components of traffic-induced urban aerosol, their spatial variation, and source apportionment, Environ. Monit. Assess, 168(1), 2010, 561-574.

[10]. N.D.Wagh, P.V.Shukla, S.B.Tambe, and S.T. Ingle, Biological monitoring of roadside plants exposed tovehicular pollution in Jalgaon city, J Environ Biol ,27(2), 2006,419-421.

[11]. S. S. Ram, S.Majumder, P. Chaudhuri, S. Chanda, , S. C. Santra, P. K. Maiti, and A. Chakraborty, Plant canopies, bio-monitor and trap for re-suspended dust particulates contaminated with heavy metals. Mitigation Adapt. Strateg. Glob. Chang., 19(5), 2014, 499-508.

[12]. E. Bashi, and N. J. Fokkema, Environmental factors limiting growth of Sporobolomyces roseus, an antagonist of Cochliobolus sativus, on wheat leaves, Trans. Br. Mycol. Soc., 68, 1977,17-25.

[13]. N. G. Buckley, and G. J. F. Pugh, Auxin production by phylloplane fungi, Nature (London), 231, $1971,332$.

[14]. R. J. Cook, and K. F. Baker, The nature and practice of biological control of plant pathogens, The American Phytopathological Society, St. Paul, Minn. 1983.

[15]. S.K. Hemida, Leaf fungi of two wild plants in Assiut Egypt, Feddes Repertorium, 115, 2004,562-573.

[16]. H. Rekosz-Burlaga, and M.Garbolinska , Characterization of selected groups of microorganisms occurring in soil rhizosphere and phyllosphere of oats, Polish J. Microbiol., 55, 2006,227-235.

[17]. C. R. Hibben, and M. P.Taylor, Ozone and Sulphur dioxide effects on the lilac powdery mildew fungus. Environ.Pollut., 9, $1975,107-114$

[18]. M. E. Fenn, P.H. Dunn, and D.M. Durall, Effects of ozone and sulfur dioxide on phyllosphere fungi from three tree species, Applied and Environmental Microbiology, 55, 1989,412-418.

[19]. P.J.W. Saunders, Effects of atmospheric pollution on leaf surface microflora, Pestic. Sci., 4, 1973, 589-595.

[20]. R.M. Mohamed, and A.E. Abo-Amer, Isolation and characterization of heavy metal resistant microbes from roadside soil and phylloplane, J Basic Microbiol, 52, 2012,53-65.

[21]. S.R. Joshi, Influence of roadside pollution on the phylloplane microbial community of Alnus nepalensis (Betulaceae), Rev Biol Trop. 56(3), 2008, 1521-1529.

[22]. E.S. DeJager, F.C. Wehner, and L. Korsten, Microbial ecology of the mango phylloplane, Microb. Ecol., 42, 2001,201-207.

[23]. W.H. Smith, Lead contamination of roadside whitepine, For. Sci., 17, 1971,195-198.

[24]. W.H. Smith, Influence of heavy metal leaf contaminants on the in vitro growth of urban-tree phylloplane fungi, Microb. Ecol., 3,1977 231-239.

[25]. W.H. Smith, Lead contamination of roadside ecosystem, J.Air.Pollut.Contr.Assoc.,6, 1976, 753-766.

[26]. K.M. Swailesh, R.M. Hussein, and S. Abu-Elhaj, Assessment of heavy metal contamination in roadside surface soil and vegetation from the West Bank, Arch.Environ. Contam. Toxicol, 47,2004, 23-30.

[27]. C.E. Shannon, Mathematical theory of communication, Bell. System. Technol. J., 27,1948, 379-423.

[28]. S. S.Ram, S. Majumder, R. V. Kumar, P. Chaudhuri, S. Chanda, S.C. Santra, P.K. Maiti, U.K. Mukhopadhyay,M.Sudarshan and A. Chakraborty, Effects of Re-suspended Roadside Dusts and Its Elemental Constituents on the Phylloplane Microflora, Asian J. Water Environ. Pollut., 10(3), 2013, 63-69.

[29]. S. K. Prajapati, and B. D.Tripathi, Seasonal variation of leaf dust accumulation and pigment content in plant species exposed to urban particulates pollution, J. Environ. Qual., 37(3), 2008, 865-870.

[30]. R.G. Mafia, A.C. Alfenas, E.M. Ferreira, G.C.G. Andrade, C.A.Vanetti, and D.H.B. Binoti, Effects of leaf position, surface, and entry sites on Quambalaria eucalypti infection in eucalypt, Trop. plant pathol., 34(1), 2009, 3-9.

[31]. G.A.Beattie, and S.E. Lindow, Bacterial colonization of leaves, a spectrum of strategies, Phytopathology, 89, 1999,353-359.

[32]. R.L.R.Mariano, and S.M. McCarter, Epiphytic survival of Pseudomonas viridiflava on tomato and selected weed species, Microbial Ecol ,26, 1993, 47-58

[33]. T.W.Mew, and C.M. Vera Cruz, Epiphytic colonization of host and non-host plants by phytopathogenic bacteria In Fokkema, N.J., Heuvel,J.V. (eds.), Microbiology of the Phyllosphere (Cambridge University Press, Cambridge, UK,1986) pp. 269-282.

[34]. J.Monge-Nájera, and M.I.González, M.R.Rossi, and V. H. Méndez-Estrada, Twenty years of lichen cover change in a tropical habitat (Costa Rica) and its relation with air pollution, Rev. Biol. Trop., 50(1),2002, 309-319.

[35]. A. Sandhu, L. J. Halverson, and G.A. Beattie, Bacterial degradation of airborne phenol in the phyllosphere, Environ. Microbiol., 9(2), 2007,383-392.

[36]. W. J. Manning, Effects of limestone dust on leaf condition, foliar disease incidence, and leaf surface microflora of native plants, Environ. Pollut., 2(1), 1970, 69-76.

[37]. J. L.Mowll, and G. M. Gadd, Effect of vehicular lead pollution on phylloplane mycoflora, T. Brit. mycol. Soc., 84(4), 1985,685689.

[38]. L.Brighigna, A.Gori, S. Gonnelli, and F. Favilli, The influence of air pollution on the phyllosphere microflora composition of Tillandsia leaves (Bromeliaceae), Rev. Biol.Trop.,48(2-3), 2000,511-517. 